\title{
REDUCING THE "JUSTICE GAP" THROUGH ACCESS TO LEGAL INFORMATION: ESTABLISHING ACCESS TO JUSTICE ENTRY POINTS AT PUBLIC LIBRARIES
}

\author{
Beth Bilson \\ Brea Lowenberger \\ Graham Sharp*
}

Among the strategies to improve public access to justice, increasing the accessibility and comprehensibility of legal information must be ranked as important. In this paper, the authors explore how libraries and librarians might play a role in providing the public with access and guidance to legal information. These issues are considered primarily in the context of two scenarios: that of the self-represented litigant, and that of a party to a limited scope retainer. The authors consider in particular how public libraries as public spaces and public librarians as trusted intermediaries might support the objective of greater access. The possible roles of law society/courthouse and academic libraries in training and collection development are also considered. The distinction between providing access to legal information and giving legal advice is discussed briefly, and the authors suggest some possible ways of clarifying this distinction while pursuing the goal of expanding public access to legal information.

Parmi les stratégies susceptibles d'améliorer l'accès du public à la justice, les mesures visant à accroître l'accessibilité et la convivialité de l'information juridique doivent être considérées comme des stratégies importantes. Dans ce document, les auteurs explorent le rôle que peuvent jouer les bibliothèques et les bibliothécaires en orientant le public et en lui donnant accès aux renseignements juridiques. Ce rôle est examiné principalement dans le contexte de deux scénarios : celui de la partie qui se représente elle-même et celui de la partie dont l'avocat a un mandat à portée limitée. Les auteurs se demandent notamment comment les bibliothèques publiques, à titre d'espace public, et les bibliothécaires, à titre d'intermédiaires de confiance, peuvent favoriser l'atteinte de l'objectif d'un meilleur accès à cette information. Les rôles que pourraient être appelées à jouer les bibliothèques des associations d'avocats, des palais de justice et des universités en matière de formation et d'enrichissement des collections sont également examinés. La distinction entre le fait de donner accès à des renseignements juridiques et

Beth Bilson is on faculty at the College of Law at the University of Saskatchewan, on the Steering Committee for CREATE Justice, and is the lead investigator of the Saskatchewan Access to Legal Information Project (the SALI Project) out of CREATE Justice. Brea Lowenberger is the Access to Justice Coordinator and Director of CREATE Justice (the Centre for Research, Evaluation, and Action Towards Equal Justice), and the Coordinator of the SALI Project at the College of Law, University of Saskatchewan. Graham Sharp was a third-year student at the College of Law at the University of Saskatchewan at the time this paper was written. Graham was a student in the 2015 course offering of the Dean's Forum on Access to Justice and Dispute Resolution, which the SALI Project grew out of, and fully participated in the first inter-sectoral SALI Project meeting. The SALI Project is described in detail at footnote 22. 
celui de donner des conseils juridiques est brièvement commentée, et les auteurs proposent quelques façons de clarifier cette distinction tout en veillant à élargir l'accès du public à l'information juridique.

The librarian isn't a clerk who happens to work in a library. A librarian is a data hound, a guide, a Sherpa and a teacher. The librarian is the interface between reams of data and the untrained but motivated user.

Seth Godin, author and entrepreneur

\section{INTRODUCTION: REDUCING THE “JUSTICE GAP" THROUGH ACCESS TO LEGAL INFORMATION}

Though the current discussions of access to justice cover many issues, one of the most important relates to access by people with law-related problems to trustworthy and helpful legal information. In this paper, we will look particularly at the role that librarians might play as intermediaries, facilitating access to information and providing referrals to other sources of assistance. We will suggest that public libraries, in particular, should be further considered as potential access points for legal information.

Two seminal reports on the increasing challenges for access to justice in Canada were released in 2014. A Roadmap for Change, the report of the Action Committee on Access to Justice in Civil and Family Matters, (Cromwell Report) ${ }^{1}$ and Reaching Equal Justice, the report of the Access to Justice Committee of the Canadian Bar Association, ${ }^{2}$ highlighted concerns with high costs, the complexity of the law and inaccessibility of legal information, inordinate delay, and unsatisfactory outcomes for the increasing number of Canadians who do not have reasonable opportunities to obtain legal representation or to access the justice system in other ways. The Canadian Forum on Civil Justice [CFCJ] recently found that $50 \%$ of Canadians would experience what they see as a challenging legal problem within a three-year period. ${ }^{3}$

Research has shown that more and more, the public does not view the justice system as an attainable means for resolving these legal issues. There are serious gaps in the justice system, as only a small proportion of the public can financially afford full representation, and only a small proportion of the public qualifies for assistance through provincial legal aid systems; this creates a "justice gap" with many low and middle income earners unable to access legal services. ${ }^{4}$ The statistics that evidence this gap are staggering:

1 Action Committee on Access to Justice in Civil and Family Matters, Access to Civil and Family Justice: A Roadmap for Change (Ottawa: October 2013) [Cromwell Report].

2 CBA Access to Justice Committee, Reaching Equal Justice: An Invitation to Envision and Act (Ottawa: Canadian Bar Association, November 2013) [CBA Report].

3 CFCJ-FCJC, "Everyday Legal Problems and the Cost of Justice in Canada" (May 2016) Canadian Forum on Civil Justice: Cost of Justice (Fact Sheet), online: <http://www.cfcjfcjc.org/sites/default/files//Everyday\%20Legal\%20Problems $\% 20$ and $\% 20$ the $\% 20$ Cost $\% 20$ of $\% 20$ Justice $\% 20$ in $\% 20$ Canada $\% 20$ Fact $\% 20$ Sheet $\% 20$ \%20Updated\%20May\%202016.pdf>.

4 Cromwell Report, supra note 1 at 3. 
$20 \%$ of the population take no meaningful action with respect to their legal problems, and over $65 \%$ think that nothing can be done, are uncertain about their rights, do not know what to do, think it will take too much time, cost too much money, or are simply afraid. ${ }^{5}$

Cost is the factor most frequently identified by litigants for not addressing their legal problems ${ }^{6}$ and both the CBA and Cromwell Reports noted that the mere perception that lawyers cost too much deters individuals from using the legal system. ${ }^{7}$ It is hardly surprising that there is a justice gap given the costs of legal services, combined with the complexity of legal information. The inaccessible cost of legal services is compounded by the inaccessible vocabulary associated with the law and its various procedures and institutions. ${ }^{8}$ Despite the tremendous work of public legal education associations across Canada, ${ }^{9}$ the concept of accessible legal information is complicated and multifaceted. ${ }^{10}$

The perception of the costs of lawyers is also not surprising. Lawyers have a monopoly on legal advice and the delivery of legal services, and control much legal information. The provision of legal services is, with several exceptions, exclusive to lawyers, and statutes regulating the legal profession support this monopoly. ${ }^{11}$ The rationale of the monopoly is based on the notion of quality-assurance. Admission to the practice of law is limited to persons with advanced qualifications, and this is intended, among other things, to guarantee that the quality of the information is vetted by a licensed professional. The question of whether this monopoly of legal service delivery by lawyers can be justified in the face of serious concerns about access has become more controversial in recent years, and there are signs that law societies themselves are open to exploring solutions that may limit the scope of the traditional monopoly. For example, jurisdictions across Canada and the United States are contemplating (and in several cases implementing) the licensing and training of non-lawyer professionals. ${ }^{12}$

$5 \quad$ Ibid at 4.

6 Ibid.

7 CBA Report, supra note 2 at 36; and Cromwell Report, supra note 1 at 4.

8 Cromwell Report, supra note 1 at 8, citing the 1996 Systems of Civil Justice Task Force Report.

9 For example, locally, the Public Legal Education Association of Saskatchewan (PLEA) was established to "educate, inform and empower through law-related education" and has been serving the public in Saskatchewan in this capacity since 1980. See Public Legal Education Association of Saskatchewan, "About PLEA”, online:

http://www.plea.org/about/. In terms of impact, in 2015, PLEA reported having addressed 1,151 legal information requests, completed 39 presentations across the province, 658 accounts opened on their Family Law Saskatchewan website, 629,305 website visitors, and distributed 96,623 print resources. See PLEA, “Annual Report” (2015), online: $<$ http://docs.plea.org/annual/2015AnnualReport.pdf $>$ at 5 .

10 Cromwell Report, supra note 1 at 8.

11 See e.g. section 30(1)(b) of Saskatchewan's Legal Profession Act, 1990 SS 1990, c. L-10.1. Similar provisions exist in other provinces.

12 In Saskatchewan, the Law Society and Ministry of Justice have "jointly undertaken a project to explore the possibility of expanding the scope of non-lawyer legal services providers." See Law Society of Saskatchewan, "Non-Lawyer Legal Service Provider", online: < https://www.lawsociety.sk.ca/for-lawyers-and-students/non-lawyer-legal-serviceprovider.asp $x>$. Expanding the scope of legal service delivery to non-lawyer legal service providers was contemplated by justice stakeholders in Saskatchewan at the 2015 meeting of the Dean's Forum on Access to Justice and Dispute Resolution (the Dean's Forum). See a policy discussion paper prepared by law student researchers and a synopsis of the discussion: University of Saskatchewan College of Law, "A Discussion Paper on Introducing Paralegals into the 
The option of lawyers offering limited scope retainers ("unbundled" legal services) 13 or taking on the role of "legal coach"14 has also gained popularity as a way to diversify and offer more affordable legal services to members of the public who find themselves in the justice gap. The reasons for this burgeoning regulatory and cultural shift by lawyers and law societies across Canada include the calls to action to improve access to justice, the advancement of technologies, and a recognition by many that the existing legal business model is simply not sustainable. ${ }^{15}$

Saskatchewan Legal Market” (12 March 2015), online: <http://law.usask.ca/documents/deansforum/10_NonLawyerLegalServices_PolicyDiscussion_2015DeansForum.pdf $>$ [unpublished] and "Appendix A: Summary Notes of the Third Meeting of the Dean's Forum (March 12, 2015)" in The University of Saskatchewan, College of Law, "The Dean's Forum on Dispute Resolution and Access to Justice: Progress Report II" (February 2016), online: $<$ http://law.usask.ca/documents/deansforum/11 TheThirdMeeting_2015SummaryNotes_ProgressReportII_20152016.pdf $>$ [the Progress Report II] [unpublished] at 10-11, 14, and 15-19. A consultation paper was later released by the Law Society of Saskatchewan and Ministry of Justice that, like the Dean's Forum report, outlines initiatives underway in Ontario, British Columbia, Washington State, New York State, Utah, and others. See "Consultation Paper: Expanding the Classes of Legal Service Providers in Saskatchewan" (2016), online: $<$ https://webcache.googleuser-

content.com/search?q=cache:A2IIeT8MKeUJ:https://www.saskatchewan.ca/ /media/news\%2520release\%2520backgrou nders/2016/apr/consultation\%2520paper\%2520\%2520expanding\%2520classes $\% 2520$ of $\% 2520$ legal $\% 2520$ service $\% 2520$ providers $\% 2520 \mathrm{in} \% 2520$ saskatchewan. $\mathrm{pdf}+\& \mathrm{~cd}=4 \& \mathrm{hl}=$ en $\& \mathrm{ct}=\mathrm{clnk} \& \mathrm{gl}=\mathrm{ca} \& \mathrm{client}=$ safari $>$. For scholarly commentary on the topic, see e.g. Alice Woolley \& Trevor Farrow, "Addressing Access to Justice Through New Legal Service Providers: Opportunities and Challenges" (2016) 3:3 Texas A\&M L Rev 549; and Richard Zorza \& David Udell, "New Roles For Non-Lawyers To Increase Access to Justice" (2015) 41:4 Fordham Urb LJ 1259. Sabreena Delhon, a "nonlawyer" critiques the use of this very language and promotes reaching beyond this "binary" to "[a] truly collaborative, multi-disciplinary approach that values the contributions of diverse experts," which "is crucial to the development of meaningful system change." See The Action Group on Access to Justice, "Beyond the Binary" (13 March 2017), online: Slaw <http://www.slaw.ca/2017/03/13/beyondthebinary/?utm_content=buffer6f025\&utm_medium=social\&utm_source=twitter.com\&utm_campaign=buffer $>$.

13 In a recent review of family legal services in Ontario, Justice Annemarie E Bonkalo reports that from her consultations with lawyers, it was clear that they "are enthusiastic about the potential for unbundled services to address gaps in the system" and the "availability of unbundled services was heralded by both the bench and bar as the most significant solution to the access to justice crisis." See Justice Annemarie E Bonkalo, "Family Legal Services Review" (31 December 2016), online: $<$ https://www.attorneygeneral.jus.gov.on.ca/english/about/pubs/family_legal_services_review/> (submitted to the Attorney General Yasir Nazvi and Treasurer Paul Schabas).

14 The "legal coaching" concept and supports for it has taken off in recent years. For example, in Saskatchewan, retired family law lawyer Lana Wickstrom has undertaken a position as "separation specialist," offering legal information, mediation, and separation coaching services. See Lana Wickstrom (2016), online: <https://www.lanawickstrom.com>. In British Columbia, Denice Barrie has created one-on-one coaching, workshops, and a Guidebook. See Denice Barrie, Journey to Justice: A Practical Guide to Effectively Representing Yourself in Court (Nanaimo, BC: Waymark Law, 2015); and Waymark, "About" (2017), online: <http://waymarklaw.ca/about/>. In terms of supports for legal coaching, Nikki Gershbain was awarded a Research Fellowship at the National Self-Represented Litigants Project to create a "training program for family lawyers interested in building a coaching practice." See National Self-Represented Litigants Project, "Are you a Family Lawyer? Do You Have Ideas About Legal Coaching? Fill out our Lawyer Survey Today!" (13 March 2017), online: <https://representingyourselfcanada.com/are-you-a-family-lawyer-do-you-have-ideas-aboutlegal-coaching-fill-out-our-lawyer-survey-today/>.

15 See generally CBA Report, supra note 2 and Cromwell Report, supra note 1. See also reports of the Canadian Bar Association's Legal Futures Initiative, such as CBA Legal Futures Initiative, Do Law Differently: Futures for Young 
The call to action in the CBA Report to improve access to justice recognizes that "[f]ull legal representation is not required in every case." Actions should be taken to "reduc[e] the need for representation through enhanced legal information and assistance services." 16 The improvement of access to and coordination of public legal information was also a key "innovation goal" in the Cromwell Report. ${ }^{17}$ Here, the idea was that intervention and information provided at an earlier stage of a problem could help to alleviate the need for legal assistance altogether. ${ }^{18}$ Both reports suggest that a necessary first step is to equip trusted intermediaries such as librarians, healthcare providers and others with support on how to facilitate access to legal information and provide appropriate referrals when a member of the public encounters a problem that could have legal implications. ${ }^{19}$ While public legal education associations and others have been providing high quality public legal information resources for years, and much material is now available online, the burgeoning sea of online resources makes it harder than ever for members of the public to know whether information is credible or current. ${ }^{20}$ It follows that equipping trusted intermediaries with the skills to assess sources of information and to make proper referrals is critical. While various jurisdictions are responding to the issue of access to legal information through a variety of innovative approaches, ${ }^{21}$ it is our thesis that library staff, as credible information providers, and library spaces - public, law society or courthouse, and academic - have a unique and important role to play. For many reasons, including the cost of lawyers, people are choosing to, or must, work their own way through their legal issues. Even where members of the public can afford to hire a lawyer, they may wish to be better informed about these issues, or may wish to have professional legal representation for a limited question. Thus, to improve access to justice we need to improve access not just to legal information resources, but also to intermediaries and spaces (both on and off-line) that can assist the public in navigating these resources.

From a literature review and the authors' own experience in connecting and collaborating with public, law society, and academic librarians and library staff through the recently established

Lawyers (Ottawa: February 2016), online: <http://www.cba.org/CBA-Legal-Futures-Initiative/Reports/Do-Law-

Differently-Futures-For-Young-Lawyers>.

16 CBA Report, supra note 2 at 63-64.

17 Cromwell Report, supra note 1 at 13.

18 Ibid.

19 Ibid at 12 and CBA Report, supra note 2 at 71-74.

20 Cromwell Report, supra note 1 at 13. See generally Kirsten Wurmann, The Role And Impact Of Librarians In the History and Development of Public Legal Education In Canada: A Literature Review and Annotated Bibliography (Alberta: Legal Resource Centre of Alberta Ltd., 2008) regarding the connection between librarians and the evolution of high quality public legal information resources through public legal education associations in Canada.

21 For example, the Legal Information Society of Nova Scotia has established the now award-winning "Public Navigator Project." This project, which "appears to be the first of its kind in Canada," involves "training non-legal community volunteers to provide basic legal information to people thinking about going to court who cannot afford a lawyer." See the Legal Information Society of Nova Scotia, "LISNS Public Navigator Project", online:

$<$ http://www.legalinfo.org/public-navigator-information/about-the-project.html $>$. Health intermediaries also represent a promising intermediary to provide access to legal information, which was a topic of the 2017 meeting of the Dean's Forum on Access to Justice and Dispute Resolution at the College of Law, University of Saskatchewan. A copy of the student policy discussion paper and follow-up report from the discussion will be made available online. See the University of Saskatchewan College of Law Reports: Dean's Forum Library, online:

$<$ http://law.usask.ca/research/deans-forum/library.php>. 
"Saskatchewan Access to Legal Information Project" [the SALI Project] ${ }^{22}$ we have begun to realize the true potential that partnerships between libraries and justice stakeholders could have in increasing access to credible and current legal information for the public. This paper will start by examining two of the scenarios alluded to above, which will be woven throughout the discussion: (i) that of the selfrepresented litigant [SRL] who has chosen not to enlist or cannot afford or access legal representation; and (ii) that of members of the public who choose the increasingly popular option of limited scope retainers [LSRs] (through "unbundled" legal services and/or a "legal coach"). Part II of this paper sets out these two contexts. Part III of this paper explores why libraries may have a role in providing legal information; this includes identifying the unique mandates and symbiotic roles of the law society/courthouse library, academic law library, and public library. Part IV identifies how public libraries are and can become an ideal access point for the public to solicit legal information. Our goal is that this paper will contribute to and inspire increased dialogue about how public libraries (and other innovative or existing access points) could support earlier and more integrated provision of legal information.

\section{THE SIGNIFICANCE OF LEGAL INFORMATION IN VARIOUS CONTEXTS: SELF- REPRESENTATION OR ENLISTING LIMITED SCOPE RETAINERS ("UNBUNDLED" LEGAL SERVICES)}

Many individuals may abandon claims due to increasing costs, or be forced or elect to fully or partially self-represent from the very start. This has given rise to two key contexts for members of the

\footnotetext{
${ }^{22}$ As mentioned above, the lead investigator of the SALI Project is Beth Bilson, and the coordinator of the project is Brea Lowenberger. To learn more about the SALI Project, visit University of Saskatchewan College of Law, "Saskatchewan Access to Legal Information Project", online: $<$ http://law.usask.ca/createjustice/projects/Saskatchewan-Access-to\%20LegalInformation.php>. The main objective of the SALI Project, as described on the website, is:
}

[T]o increase access to legal information for Saskatchewan residents. This project has emerged in the context of the Dean's Forum on Access to Justice and Dispute Resolution. In its deliberations, the forum identified access to legal information as one of the critical components of access to justice.

As a first step, a one-day action-oriented meeting was held on Sept. 12, 2016 at the College of Law between several dozen justice stakeholders and library representatives to discuss how library representatives, as intermediaries and credible information providers, could help improve access to justice in Saskatchewan. The meeting was generously supported by a University of Saskatchewan President's Social Sciences and Humanities Research Council (SSHRC) grant.

A number of themes and action items emerged from the day's discussions, as was documented in the Law Society of Saskatchewan Bencher's Digest, and on the College of Law website. From the momentum of the event, the SALI Project was established. The SALI Project partners and participants are in the process of implementing these next steps, which includes hosting a conference on October 20-21, 2017, during the Second Annual Saskatchewan Access to Justice Week. The primary purpose for the event will be to bring together a large number of public library representatives from rural, remote, and small urban centres in Saskatchewan as well as experts in the topic area, to further address how greater access to legal information can be achieved through partnering with libraries. [hyperlinks omitted] 
public in the justice gap: (i) that of self-represented litigants; and (ii) that of those who enlist limited scope retainers, colloquially referred to as "unbundled legal services." We recognize that this categorization does not capture all of the reasons why people might seek legal information, but since these two examples are prominent in the current discussion of access to justice issues, we will focus attention on them.

\section{A. The Context of Assisting Self-Represented Litigants}

Resulting from the "endemic problems in the civil justice system" is what Chief Justice McLachlin of the Supreme Court of Canada labelled an "epidemic of lack of representation."23 Self-represented litigants are those who have chosen to act as their own legal representatives in different kinds of legal proceedings, including in court. Some of them have chosen this route because they are confident that they can address their own legal issues in a more satisfactory way than a lawyer, but many of them are driven to this course because they cannot afford the cost of professional legal services. Self-represented litigants (SRLs) present challenges not only to the justice system, but also to society more broadly. For the most part though, SRLs themselves must deal with these challenges. They are understandably unfamiliar with the procedures and the value of their legal problem, but just as importantly, they often lack legal research abilities and resources. ${ }^{24}$

A day in court is not enough - the legal service needs of SRLs must be met in order to ensure they receive meaningful access to justice. Julie Macfarlane conducted a seminal Canadian study on the incidence and experiences of SRLs. ${ }^{25}$ She stresses the need to "shatter the stereotype." ${ }^{26}$ When SRLs are disempowered by an intimidating and costly legal system, the burdens that they face render the justice system's promise of equal access illusory. ${ }^{27}$ Similarly, study participants cited in the CBA Report stated how "ignorance of one's legal rights renders them useless" and since information "is not readily available," this ignorance is difficult to overcome. ${ }^{28}$ The studies bear out that this SRL epidemic pervades not only low-income and marginalized sectors of society, but is a lower working and middleclass phenomenon, one that Kara Noel in part attributes to the "increasing costs [of] legal information" that ultimately hinders the ability of litigants to afford "the high cost of legal representation." 29

23 Unbundling of Legal Services Task Force, Limited Retainers: Professionalism and Practice, (Vancouver: The Law Society of British Columbia, April 2008) at 3.

24 Kari D Boyle, "Enhancing Access to Justice by Combining Unbundled Legal Services and Mediation" (31 October 2013), online: Slaw $<$ http://www.slaw.ca/2013/10/31/enhancing-access-to-justice-by-combining-unbundled-legalservices-and-mediation/>.

25 Julie Macfarlane, The National Self-Represented Litigants Project: Identifying and Meeting the Needs of SelfRepresented Litigants: Final Report (2013), online: <http://representingyourselfcanada.com/wpcontent/uploads/2015/07/nsrlp-srl-research-study-final-report.pdf $>$.

26 Julie Macfarlane, "Time to Shatter the Stereotype of Self-Represented Litigants" (2013) 20:1 Dispute Resolution Magazine 14.

27 See generally Macfarlane, supra note 25.

28 CBA Report, supra note 2 at 20.

29 Kara Noel, "The Unbundling of Legal Services and Its Implications for Law Librarianship" (2015) 34:4 Legal Reference Services Q 245 at 246. 
Yet, there is also a segment of SRLs who choose to self-represent, in part or in full. ${ }^{30}$ The ability to access legal information is considered by the CFCJ to be part of "self-help services," lying on the opposite end on the legal services "continuum" from full representation. ${ }^{31}$ Indeed, improving access to justice involves what the CBA has called for in building a "participatory justice system," and "transcending the SRL phenomenon" to recognize SRLs as an "accepted fixture of our justice system," 32 and a feature which may signify greater self-determination on the part of individuals facing legal proceedings.

Although some members of the public may choose to self-represent, scholars such as John Malcolmson argue, "[i]n-person service is people's first choice" but where help from a legal service provider is impossible, the option "could be to focus on a community intermediary supported in the use of legal resources." "33 Since "the need for low cost and free legal information and services will continue to grow," 34 members of the public will increasingly turn to any and all institutions able to provide them some assistance in their legal matter. We argue that public libraries and their staff, as existing trusted intermediaries and credible information providers, have an important role in providing access to legal information to SRLs, as well as those who enlist limited scope retainers (unbundled legal services), which context is discussed next.

\section{B. The Context of Assisting Those Enlisting Limited Scope Retainers (Unbundled Legal Services)}

It is not only those who choose or have no choice but to self-represent that need support in navigating the complex vocabulary of the law and its procedures and processes. The term "unbundled legal services" refers to "discrete task representation or limited service representation." 35 The concept recognizes that full representation by a lawyer may not be needed in every case, or for every aspect of a case. ${ }^{36}$ Members of the public may choose to use LSRs specifying what representation a lawyer will provide; to have "equal access," these people also require credible, current legal resources, and assistance in accessing legal information.

While it is beyond the scope of this article to examine the benefits and shortcomings of LSRs, ${ }^{37}$ the advantages cited for this option are at least two-fold. The use of LSRs can be more empowering and also more affordable, as the client handles those parts of their matter that do not require specialized

30 See e.g. CBA Report, supra note 2 at 63-64. Many people, as asserted in the CBA Report, "want to be active participants in preventing and resolving legal problems."

31 Canadian Forum on Civil Justice, Rural \& Remote Access to Justice: A Literature Review, (Toronto: Rural and Remote Access to Justice Boldness Project, November 2015) at 25.

32 CBA Report, supra note 2 at 63.

33 John Malcolmson, Voices from the Field: Needs Mapping Self-help Services in Rural and Remote Communities (British Columbia: Supreme Court Self-Help Information Centre, 2008) at 89.

34 Deborah Hackerson, "Access to Justice Starts in the Library: The Importance of Competent Research Skills and Free/Low-Cost Research Resources” (2010) 62:2 Maine L Rev 473 at 474.

35 Alison MacPhail, Report of the Access to Legal Services Working Group (Action Committee on Access to Justice in Civil and Family Matters, 2012), online: <http://www.cfcjfcjc.org/sites/default/files/docs/2013/Report\%20of\%20the\%20Access\%20to\%20Legal\%20Services\%20Working\%20Gr oup.pdf $>$ at 11 .

36 Ibid.

37 For more, see e.g. MacPhail, ibid. 
knowledge. This approach thereby eases the issue of cost, while empowering the client to be a participant in their legal process, achieving the "participatory justice system" that the CBA Report endorses. ${ }^{38}$ If members of the public are to enter into LSRs and handle aspects of their own case, however, there is and will continue to be a need for accessible substantive and procedural legal information resources and trusted and knowledgeable intermediaries who can provide appropriate referrals for credible and current resources.

\section{WHY LIBRARIES? THE ROLE OF LIBRARIES AS INTERMEDIARIES FOR ACCESS TO LEGAL INFORMATION}

Libraries could become crucial partners and resources for battling access to justice challenges in Canada, specifically for assisting SRLs and LSR clients with accessing legal resources, by becoming more accessible and effective in this role. Easy and effective access to legal information is vital to resolving legal issues, and library staff members are natural and appropriate intermediaries for this purpose. Law society or courthouse libraries, academic law libraries, and public libraries typically have distinct mandates, clientele, and locations. The role of libraries as community intermediaries generally, and more specifically the potential roles of each of the three library systems in helping to improve access to legal information, are discussed below.

\section{A. Roles of Libraries in Supporting SRLs and LSR Clients Access Legal Information 1. Role of Library Staff as Intermediaries in Assisting Patrons with Navigating Legal Information Resources}

(a) Library staff can be trusted intermediaries and credible information providers

Professional librarians and other library staff are perhaps natural candidates for the role of "community intermediary" in relation to legal information. The American Association of Law Libraries [AALL], an organization whose members come mainly from law society libraries, law school libraries and law firm libraries, has acknowledged the Macfarlane study and recognized the need to serve the growing population of SRLs. ${ }^{39}$ In their view, answering this call means "more engagement and innovation" in defining the distinction between legal information and legal advice and collaborating on online information resources, among other initiatives. ${ }^{40}$ The distinction between legal information and legal advice will be considered briefly in this paper but the broader connection between legal information and access to justice, along with the potential incorporation of libraries in the overall service model, is an important initial discussion.

With the complexity of legal information, and when the costs of legal representation are as high as they are, the potential of libraries as trusted intermediaries for improving access to justice is apparent, given their informational and educational capacity. As with other access to justice initiatives, access to information must be more than mere availability, it must be meaningful. The AALL's report contends:

38 CBA Report, supra note 2 at 63.

39 Special Committee on Access to Justice, Law Libraries and Access to Justice (Chicago: American Association of Law Libraries, July 2014) at 23.

$40 \quad$ Ibid at 24. 
Access to justice requires that the public have available understandable information about the justice system, its resources, and means of access. The justice system should promote ongoing public knowledge and understanding of the tools afforded by technology to access to justice by developing and disseminating information and materials as broadly as possible in forms and by means that can reach the largest possible number and variety of people. ${ }^{41}$

If legal representation is not chosen or cannot be guaranteed, SRLs and LSR clients must be equipped with, or able to access, the necessary tools to address their legal problems. Though her piece is focused on the importance of lawyer research skills, Deborah Hackerson argues that access to justice necessarily includes access to information. ${ }^{42}$ She believes, "[i]n order to help anybody in need the information and resources must be available" as those "who cannot afford lawyers need to have ready access to the tools used by lawyers in their practice of law." ${ }^{43}$ Similarly, Karen Cohl and George Thomson state, "[k]nowledge of legal rights is an essential element of access to justice" and "[e]arly access to accurate information... aiding in understanding how legal matters intersect" is of fundamental importance. ${ }^{44}$

The CFCJ highlights the crucial link between this intersection of legal matters and other non-legal issues: "The literature on access to justice recognizes that legal problems are interrelated and are often indivisible from other socio-economic and demographic issues." ${ }^{25}$ This can lead to referral fatigue for that individual and worse, "general service deficits" complicating "the ability to address overlapping legal needs. ${ }^{" 46}$ Restating the challenge of ensuring effective access to justice, Cohl and Thomson argue:

Truly accessible information enables the person to identify and understand the legal problem, on its own and in its broader context. It is not sufficient simply to make the information available on line or in written format. People need to connect legal information to their own circumstances. Often, they need someone to help them define the problem, find the relevant information, apply the information to their situation, and make referrals to legal professionals who can advise and represent them in legal matters. ${ }^{47}$

Of course, such assistance could potentially rise to the level of unauthorized practice of law, a consideration to be addressed later, but the reality is that basic access to information, without guidance from an intermediary, will rarely be enough.

The expertise of librarians lies in assessing the value and credibility of sources of information and in matching the needs of users with information relevant to those needs. Providing librarians with the skills

$41 \quad$ Ibid at 16.

42 Hackerson, supra note 34 at 480.

43 Ibid.

44 Karen Cohl \& George Thomson, Connecting Across Language \& Distance: Linguistic and Rural Access to Legal Information and Services (Toronto: Law Foundation of Ontario, December 2008) at 5.

45 Canadian Forum on Civil Justice, supra note 31 at 16.

46 Ibid.

47 Cohl \& Thomson, supra note 44 at 52. 
they need to deploy this expertise in the context of legal information would make them a powerful resource for members of the public seeking information related to their own legal problems. Though some librarians, notably those in academic and professional law libraries, have training which allows them to understand and navigate legal indexes, databases, textbooks, and other legal resources, many librarians have a more generalist mission. Figuring out how to build on the expertise and knowledge of different categories of librarians to broaden access to legal information for the public is a significant task.

\section{(b) The Public's Need for Legal Information and Intermediary Assistance is on A Spectrum}

An individual must know when they have a legal problem, but further, where to go for help. ${ }^{48}$ Unfortunately, people "seldom look for legal information or support until their situation has become a crisis [and they] don't have the language for their problem."49 Michele Leering's Five County Connecting Region Project in Ontario noted that low literacy and lack of education are more likely to lead to individual failure to recognize legal rights, compounded by individuals' frequent confusion about where to go for help once they acknowledge there is a problem. ${ }^{50}$ Ensuring every individual can recognize when they have a problem is a near-impossible task, but helping them identify when a problem is in fact a legal one is not. Once they become aware of a problem involving the justice system, people naturally "want early access to legal information and assistance; long before the day of a court proceeding." ${ }^{51}$ Provided that an individual is aware that their problem may be a legal one, they desire early access to crucial information.

As the CFCJ points out, "[w] hether legal information acts as a supplement to a wider array of justice services, or serves as a standalone resource, it is equally valuable to recipients." ${ }^{2}$ They continue, suggesting, "static legal information has a number of advantages, such as the ability to reach a wide audience and remain relevant." ${ }^{53}$ Of course, as mentioned, access to justice is "more than access to information," 54 which is why the Five County Project was "committed to improving access to justice by increasing access to both legal services and legal information through collaborative strategies between legal and non-legal community organizations." ${ }^{55}$ Malcolmson also stresses the importance of "links into community-level services capable of supporting the non-legal needs of individuals facing legal challenges," asserting that "coordination is needed for reforms aimed at improving access."

It might be said that rarely is self-help entirely independent. In particular, if literacy or cognitive ability is low then effective self-representation may be impossible without some institutional assistance.

$48 \quad$ Ibid at 15.

49 Five County Connecting Region Project, Paths to Justice: Navigating with the Wandering Lost Providing Access to Justice in Rural and Linguistic Minority Communities in South-Eastern Ontario (Belleville: Community Advocacy \& Legal Centre, 2011) at 15.

$50 \quad$ Ibid at 16.

51 Ibid at 11 .

52 Canadian Forum on Civil Justice, supra note 31 at 49.

53 Ibid.

54 Five County Connecting Region Project, supra note 49 at 38.

55 Ibid.

56 Canadian Forum on Civil Justice, supra note 31 at 10. 
A 2008 report on rural self-help in British Columbia "emphasized that clients are most likely to use selfhelp materials effectively if they have a high level of literacy, comprehension, and confidence" and further, that "self-help materials may not be suitable for people facing multiple barriers." 57 These barriers may include illiteracy, language issues, cognitive difficulties, or mental health issues. Though many citizens are capable of reading and interpreting information at a fairly sophisticated level, most members of the public will require some level of guidance or assistance.

The term "self-help" may not accurately describe a situation where there is a need for an effective intermediary who can "provide guidance, problem-solving and searching skills, and support greatly enhanc[ing] the effectiveness of self-help materials." 58 There are clear benefits to SRLs or LSR clients being able to "interact with a "live person." 59 Intermediaries have a "powerful role to play by incorporating problem-solving skills training into general advice or client contact work." ${ }^{\prime 60}$ Fulfilling this role will improve access to justice by enhancing overall and effective access to legal information. Those seeking "the front door to services in rural and remote areas," for example, are said to "rely heavily on a network of legal and non-legal service providers." ${ }^{.1}$ Community networks end up being the lifeline. Malcolmson relates how in small communities "there are 'go-to-people... who assist others to find and use services [and the] research indicates that these people may be librarians," ${ }^{, 62}$ who are well positioned to provide an access to justice "entry point." ${ }^{\prime 3}$ Malcolmson argues that these individuals become key intermediaries between the client and the legal service when they "know how to access legal resources and whom to call for more guidance." ${ }^{\prime 4}$ As a result, "support for local service providers emerged as an aspect of necessary local capacity-building required to deliver rural and remote service." applies equally to urban centres, in neighbourhoods where resources are lacking.

That legal information must be effectively accessed in order to be a true resource has already been outlined. Cohl and Thomson set out that legal information "from an intermediary or a website, if it enables individuals to apply the information to their specific circumstances, can be the foundation either for an appropriate referral or for a decision to proceed on their own." ${ }^{66}$ Libraries are the ideal entry point for people with diverse needs requiring access to such legal information assistance. ${ }^{67}$

\section{Role of Library Spaces in Providing Free Access to Technology and Online Legal Information}

It is crucial to note that libraries can effectively promote access to useful technologies. ${ }^{68}$ More and more, the so-called "digital divide" is a "significant obstacle."

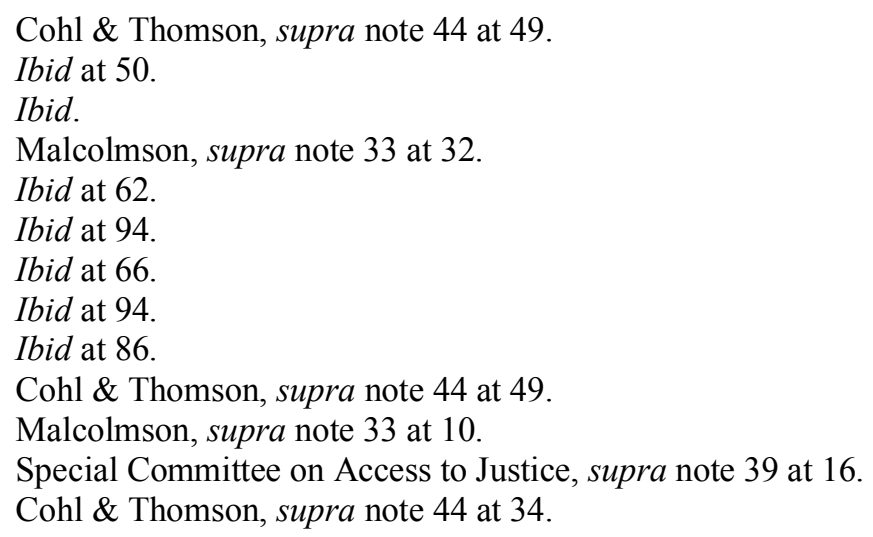


academic libraries, may place limits on access to technology, public libraries almost always provide free internet, thus playing a critical role in "reducing the "digital divide." "70 Libraries facilitate access to justice when they help patrons (SRLs or LSR clients) access the growing number of free or nominal-cost online legal advice resources. ${ }^{71}$ Free access to computers and the internet can be further supplemented with training of "library staff to better assist [their] patrons in finding relevant legal information," 72 which is further described in Part III. Thus, Malcolmson argues for "the approach of 'technology with a helper," ${ }^{\prime 73}$ where an intermediary, such as a librarian, is connected with the technology and can thereby improve a patron's access to it. This is especially necessary given the aforementioned lower level of literacy and inadequate technological skills found among some individuals in rural and remote areas. Seeking assistance from an intermediary is crucial for SRLs or LSR clients using online legal resources in rural and remote areas. Since SRLs (and by extension, one can imagine, LSR clients) generally only identify legal problems with the assistance of a service provider, ${ }^{74}$ a trusted intermediary's guidance with offline legal resources can be just as valuable.

Though print materials continue to play a role, resources that must be accessed by technological means are increasingly important for people dealing with legal issues. Many libraries, particularly public libraries, have seen it as part of their responsibility to make it possible for patrons - whether lawyers, judges, law students, or members of the public - to have access to the technology they need to access information in digital form. Though it cannot be assumed that technology is equally accessible or available in all geographic regions, a problem we are unable to explore here, there is no question that one of the critical roles libraries now play is that of providing access to and guidance about information resources available through technological means. ${ }^{75}$

With respect to legal information resources, both print and digital, and the provision of assistance in accessing those materials, different kinds of libraries have different mandates, and we outline those below.

\section{B. Roles of Law/Courthouse Libraries, Academic Law Libraries, and Public Libraries: A Symbiotic Relationship}

More members of the public are "flocking to law library reference desks," and Steven Anderson points out that this is "because of the move toward 'do-it-yourself' legal actions, such as filings in 'small claims courts' and 'no-fault' divorces, and the reduction of legal services to the poor."

70 Michele Leering, Libraries \& Access to Justice Outreach: Project Report \& Resources (Belleville: Community Advocacy \& Legal Centre, October 2015) at 3 [Leering, "Libraries"].

71 Noel, supra note 29 at 245.

72 Canadian Forum on Civil Justice, supra note 31 at 41.

73 Malcolmson, supra note 33 at 11.

74 Five County Connecting Region Project, supra note 49 at 15.

75 A recent libraries study in Australia found that the "library of the future" which is currently being rolled out, "not only continues to provide access to literature... but also has the leading edge technology to ensure that access is offered to all members of the community." Civica, "The Intrinsic Value of Libraries as Public Spaces," Report to the University of Technology Sydney, October 2016, online:

$<$ https://www.uts.edu.au/sites/default/files/Civica\%2BIntrinsic\%2Bvalue\%2Bof\%2Blibraries\%2Breport.pdf $>$ at 3.

76 Steven P Anderson, "Communications Conflict at the Law Library Reference Desk: A Survey of General Library Science and Communications Literature" (1998) 16:4 Legal Reference Services Q 5 at 6-7. 
courthouse libraries, academic law libraries, and public libraries have developed, in some cases, as is explained next, a symbiotic relationship. Charles Condon highlights how in some communities, "cross referrals involving law libraries, courts, law schools, and public libraries are quite common."77 The symbiotic yet unique mandates of these libraries as they relate to the provision of legal information are described in the following subsections.

\section{Role of Law/Courthouse Libraries in Improving Access to Legal Information}

Law libraries located in courthouses can make a major contribution "to removing some of the roadblocks in the legal process" 78 by employing their "knowledge, skills, and resources to provide selfrepresented litigants with needed information and assistance and provide referrals to legal resources in the community." $" 79$ Specific familiarity with legal reference materials, as well as additional education in legal issues, makes staff in courthouse libraries potential leaders as coordinators in the assistance of legal information provision to SRLs and LSR clients. The AALL claims law/courthouse libraries are in a unique position to assist such patrons: "[They] are skilled in the reference interview...have legal reference materials...a more comprehensive knowledge of primary resources in multiple subject areas... [and are] skilled at searching the Internet." ${ }^{10}$ Staff members of courthouse libraries, as well as some of the staff in court registry offices, are familiar with the links between legal information and different kinds of legal proceedings, and with court procedures and requirements. Their physical location means that people involved in court proceedings often seek assistance from them because of their proximity. There are certainly instances of initiatives undertaken by the staff of courthouse libraries in order to address more directly access to justice issues. In Regina and Saskatoon, for example, the law society libraries in the superior court courthouses have hosted public information sessions on family law issues sponsored by the Ministry of Justice.

Notwithstanding the readiness of courthouse library staff to expand their role in improving access to justice, there are some limits on the extent to which these libraries can play this role. In most courthouses, for example, security screening is a requirement for everyone entering the courthouse, which may inhibit members of the public from thinking of these libraries as an accessible source of information. In addition, since the collections in courthouse libraries are largely paid for by members of the legal profession through their professional fees, they tend to consist mainly of materials that serve the demand of the legal profession for specialized information, and may not include the range of more accessible resources that would be required to meet the needs of the public.

It is our view that these libraries could probably play a more effective role in increasing access to legal information in indirect ways - by providing training and support to public librarians, for example, and by making their specialized resources available in appropriate cases through interlibrary loans or other vehicles. Staff of courthouse libraries could also respond to particular patrons referred to them by public librarians for assistance with a specialized legal issue.

77 Charles J Condon, "How to Avoid the Unauthorized Practice of Law at the Reference Desk" (2001) 19:1-2 Legal

Reference Services Q 165 at 173.

78 Special Committee on Access to Justice, supra note 39 at 27.

79 Ibid at 5.

$80 \quad$ Ibid at 31. 


\section{Role of Academic Law Libraries in Improving Access to Legal Information}

Academic law library staff members are also "obvious candidates for promoting access to justice" given their involvement in research instruction, ${ }^{81}$ reference assistance to the public (when open publicly), and computer access for online legal resources. ${ }^{82}$ In fact, these librarians are "expert legal researchers and enjoy sharing their knowledge about legal research strategies and resources;" like law/courthouse librarians, they may be able to play an important part in promoting access to justice by teaching public and academic non-law librarians basic legal research skills. ${ }^{83}$ They can also "recommend core collections of primary and secondary legal materials for self-represented patrons. ${ }^{84}$ Academic law libraries may have a wider range of legal resources than courthouse libraries, as the latter tend to be focused more particularly on resources relevant to legal practice and judicial proceedings. Academic libraries, with their focus on research as well as professional preparation, are likely to have more diverse and critical perspectives included in their collections.

Academic law librarians offer much in the way of skills and expertise relevant to access to justice issues. In particular, they have considerable experience dealing with students and people from non-law disciplines whose familiarity with legal information is limited. Academic law librarians are as helpful as they are able to be to members of the public who approach them for assistance. Academic law librarians help members of the public who approach them for assistance to the best of their abilities. Universities are public institutions, and as such their campuses - and libraries - are generally open to the public. The fact remains, however, that universities are also large, complex and confusing physical spaces. In addition, those members of the public perhaps most in need of assistance in accessing legal information may not find the academic environment a comfortable or congenial one.

\section{Role of Public Libraries in Improving Access to Legal Information}

Public libraries have traditionally been important civic spaces. As a study of public libraries in Nova Scotia put it, "[p]ublic libraries are central places where members of the community feel welcome, and this may be particularly important in disadvantaged communities." ${ }^{.85}$ A study of libraries in Australia quoted one respondent as describing the library as a place "genuinely welcoming to all. There are very few places where anybody can go, know that they are welcome to come in, they're not going to be changed, they're not going to be sold anything, and a range of supportive friendly services will be available." $" 86$

Not only are public libraries accessible spaces in their own communities, they tend to be present in smaller and more remote centres ${ }^{87}$ when courthouse and academic law libraries are not. The character of public libraries as existing community hubs which draw patrons from all segments of the community's

81 Ibid at 34.

82 Ibid at 36.

83 Ibid at 37.

84 Ibid at 38 .

85 Francine May \& Fiona Black, "The Life of the Space: Evidence from Nova Scotia Public Libraries" (2010) 5:2 Evidence-Based Library and Information Practice 5 at 23.

86 Civica, supra note 75 at 7.

87 The recent study of Australian libraries identified that "[i]n small and remote areas the role of the library will be pivotal to the process of disseminating community support and information." Civica, ibid at 14. 
population $^{88}$ make them worth considering more closely as players in increasing access to legal information. Many public libraries do maintain collections of law-related resources, and public librarians are skilled at helping patrons determine what kinds of information they need. With their generalist mandate, however, they do not always have specific training to assist them in the assessment of different sources of legal information. ${ }^{89}$

The possibility that specialized law librarians might be able to transfer their knowledge of legal information to public library staff members has scholars such as Noel arguing that public library staff "should embrace their potential role in facilitating access to the information available to patrons" 90 She points out that the AALL "strives to facilitate the 'open and effective access to legal and related information,' and maintains that 'the availability of legal information to all people is a necessary requirement for a just and democratic society." "91 Courthouse and academic law libraries are likely better equipped with collections and are thus an important resource for aiding in the development of legal collections, reference assistance, and referrals in the public library. The AALL notes "law librarians and public librarians have come to rely on each other to enhance access to justice" 92 in a codependent way. As described above, academic law libraries similarly have well-developed collections and thus have an important collaborative role with law/courthouse libraries and public libraries.

Despite the important role that each library system plays in in enhancing access to justice, researchers have found that public libraries continue to be "on the front line, assisting patrons with legal questions regularly." 93 Public librarians can be better supported in improving their capacity for providing inperson assistance ${ }^{94}$ for patrons. The Five County Project found an interest among public library staff to improve their capacity to provide legal information for patrons:

The librarians were very interested in increasing access to legal information through the libraries, which already serve as community hubs, particularly in the rural areas. Furthermore, these libraries are part of wider networks... The participants discussed the

88 See e.g. Julie Biando Edwards, Melissa S Rauseo, \& Kelley Rae Unger, "Community Centred: 23 Reasons Why Your Library is the Most Important Place in Town" (30 April 2013), online: A Publication of the Public Library Association, Public Libraries Online <http://publiclibrariesonline.org/2013/04/community-centered-23-reasons-why-your-library-isthe-most-important-place-in-town/ $>$ [unpublished]. The impact of library services, these authors argue, make public libraries the "most important place in town," as they function "as community builders," "as community centers for diverse populations," "as universities," and more. In a movement toward creating "learning cities" which focus on the provision of "lifelong learning," public libraries appear to be a central aspect to such communities. For example, in Namyangju in the Republic of Korea, "a library is no more than thirty minutes ... away" from each resident, "no matter where they live in the city": Raúl Valdes-Cotera, et al, eds, Unlocking the Potential of Urban Communities: Case Studies of Twelve Learning Cities (UNESCO Institute for Lifelong Learning: Hamburg; and the National Institute for Lifelong Education: Republic of Korea, 2015) at 138.

89 The study of Australian libraries revealed that library managers recognize that "they would need to gain new and broader skills in order to provide the library services of the future." Civica, supra note 75 at 14.

90 Noel, supra note 29 at 245.

$91 \quad$ Ibid at 262-263.

92 Special Committee on Access to Justice, supra note 39 at 10.

$93 \quad$ Ibid at 27.

94 Malcolmson, supra note 33 at 81. 
kinds of library users who are looking for legal information as well as the kinds of legal information (primarily family and housing) they are seeking. Library staff would like to receive legal information and referral training and to be provided with public legal education resources as well as recommended reference materials on legal topics. ${ }^{95}$

The AALL reinforces that law/courthouse libraries can partner with the public libraries to aid them to reach individuals "who may not be aware of the local public law library and its services." ${ }^{\text {" }}$ Public librarians often refer patrons to a law/courthouse library, which in turn relies on the public library "for easy computer access, services during non-courthouse hours, and as gateways to law library and legal information service providers. ${ }^{.97}$ The partnership of law/courthouse libraries and academic law libraries with public libraries is critical because public libraries are more numerous, are more dispersed geographically and typically offer evening and weekend access. ${ }^{98}$ While law/courthouse libraries play an important role in supporting the provision of legal information resources to the public, the unique role and promise of public libraries and their staff and space is apparent, which idea is developed next.

\section{HOW? ESTABLISHING ACCESS TO JUSTICE ENTRY POINTS AT PUBLIC LIBRARIES}

\section{A. The Promise of Public Libraries in Improving Access to Legal Information}

Establishing access to justice entry points at public libraries, backed up by training and specialized reference services from specialized law libraries, represents a promising approach to improve the provision of legal information to the public, and thus reduce the justice gap. One of the most notable benefits of public libraries is their service location and "social relations of place." Public libraries, with their objective to meet the needs of the public, take into account that "how and where" programs and services are offered is important. ${ }^{99}$ As a result of their aim to meet the diverse needs of their communities, public libraries are typically welcoming, unencumbered spaces located in accessible areas. ${ }^{100}$ Contrastingly, the mandate, space, and location of law/courthouse libraries and academic law libraries are not as accessible.

95 Five County Connecting Region Project, supra note 49 at 22.

96 Ibid.

97 Ibid.

98 Ibid.

99 Saskatoon Public Library, "About” (2017), online: <http://www.saskatoonlibrary.ca/splboard>.

100 Notably, public libraries are, as Maija Berndtson, argues, "in fact some of the few public places and spaces left in most cities." Berndtson further explains that,

Public space is a vague concept, but public spaces are for example those that are open and accessible to all, regardless of gender, race, ethnicity, age, or socio-economic level, such as town squares and parks. However, traditions related to 'the commons' have suffered with increased privation: for example shopping malls with appearance of being a 'public space' - but are actually privately owned public spaces.

Maija Berndtson, "Public libraries and placemaking" (Paper delivered at the IFLA World Library and Information Congress: $79^{\text {th }}$ IFLA General Conference and Assembly, Singapore, (30 May 2013), online: IFLA Library

$<$ http://library.ifla.org/224/> at 3 . 
Related literature supports public libraries as promising entry points in improving access to legal information for the public. Malcolmson, for example, stresses the importance of service location ${ }^{101}$ and such a recognizably public place as a public library should enhance the comfort level and confidence of those attending the location for legal assistance. The CFCJ also alludes to the "[s]ocial relations of place," which in the context of the CFCJ report refers to the way in which "the interaction and actions of residents in rural communities... influence help-seeking behaviour." 102 Expanding more generally on the idea of the concept of "space," the AALL asserts that libraries are "spaces that allow connection and privacy, problem-solving resources, and an educational environment that promotes access to technologies." 103 The patron feedback on their use and experience of library spaces from a study of Nova Scotia libraries parallels the AALL's findings. In the Nova Scotia study, patrons described libraries to include "the role of provider of books and information, provider of access to technology and provider of a social space where members of the public are welcome." 104 The Five County Project also recognized the importance of "providing legal information and services in public, multi-purpose settings like libraries" that still allow for some privacy and anonymity. ${ }^{105}$ Libraries are often the only free community space, ${ }^{106}$ and the AALL confirms that the library space is a recognized self-help resource centre. The promise of public libraries in improving access to legal information is apparent.

There are already some noteworthy projects in place in Canada using public libraries "as public legal education resource centres," such as the BC Courthouse Library LawMatters project ${ }^{107}$ but possibly the most important work that is being undertaken is the training and capacity building provided to public libraries and library staff themselves. It is also important to promote public libraries as places people are able to access for assistance with their legal problems. If public libraries are to be imagined asaccess to justice entry points, or trusted intermediaries, more formal relationships must be fostered between them and legal service providers so that they can provide "better legal information and referral for vulnerable clients." 108 The need for formal partnerships between public libraries and legal service providers in order to encourage legal information provision and the public soliciting legal information at libraries has been determined in several recent studies. Cohl and Thomson found it difficult "to identify with precision where [rural and remote residents] now go for essential legal information." 109 The Family Legal Education for Women project did not find that libraries were one of those sources. ${ }^{110}$ Furthermore, legal

101 Malcolmson, supra note 33 at 85. More generally, see the work of Gloria J Lecki \& Jeffrey Hopkins, “The Public Place of Central Libraries: Findings from Toronto and Vancouver" (2002) 72:3 The Library Q: Information, Community, Pol 326 at 331-333 regarding the "public library as success public space."

102 Canadian Forum on Civil Justice, supra note 31 at 37.

103 Ibid at 28-29. See also Henrik Jochumsen, Casper Hvenegaard Rasmussen \& Dorte Skot-Hansen, "The four spaces - a new model for the public library" (2012) 113:11-12 New Library World 586 at 589. These authors envision and propose a new model for public library space, which includes "inspiration space," "performative space," "learning space," and "meeting space."

104 May \& Black, supra note 85 at 5.

105 Five County Connecting Region Project, supra note 49 at 21.

106 Leering, "Libraries", supra note 70 at 3. See also Berndtson, supra note 101 at 3.

107 Cohl \& Thomson, supra note 44 at 37.

108 Ibid at 44.

109 Ibid at 43.

110 Ibid. 
service providers are beginning to recognize how non-legal problems can arise by virtue of legal ones, which has led them to "explore partnerships" with trusted intermediaries and community organizations. ${ }^{111}$ Often it is through these trusted intermediaries that people can find their way to legal services while receiving service for another issue. ${ }^{112}$ If individuals are at least able to recognize they have a legal problem requiring access to legal information, they could identify the public library as a primary access point for assistance, especially if public libraries improve their capacity, and therefore credibility, in providing effective access to appropriate legal information, and in referring patrons to legal or other services.

Librarians, as trusted intermediaries, "are likely to know the community members and be one of the first points of contact for those in need." 113 Community members have a certain comfort level with local organizations, which can position themselves as trusted intermediaries. According to the CFCJ's research:

[T] he tight-knit nature of communities and their strong community networks can enhance information sharing between community members and organizations... Utilizing these networks and engaging "trusted intermediaries" can help build confidence in the system... and allow for communities to "buy in" 114

Although there is never any guarantee that people will actually access available services, ${ }^{115}$ such capacity building efforts outlined below could help meet the objective of establishing public libraries asentry points for access to justice. Work has begun in some jurisdictions, in various ways, to improve the capacity of public libraries, in collaboration with other library systems, to provide accessible legal information, exemplifying the promise of the role of public libraries in improving access to legal information. The following section further establishes the public library as an access to justice entry point.

\section{B. Building the Capacity of Public Libraries to Help Reduce the "Justice Gap" 1. Current Legal Information Initiatives with Libraries in Canada}

There are several promising initiatives underway in conjunction with public libraries in Canada in addition to the SALI initiative, as well as some developments that are long established. These initiatives cover a spectrum of options, from simply improving the legal information collections of public libraries, to engaging in dynamic partnerships with legal professionals who provide some on-site legal services or advice. Free high-speed internet access is common in most public libraries and Industry Canada's Community Access Program has expanded access in rural and remote areas. ${ }^{116}$ Family Law Information

111 Canadian Forum on Civil Justice, supra note 31 at 17.

112 Five County Connecting Region Project, supra note 49 at 15.

113 Canadian Forum on Civil Justice, supra note 31 at 39.

114 Ibid at 38-39.

115 Though Berndtson suggests to her fellow librarians to be proactive in describing the "value of public space for...cities and neighborhoods" and to "see the role of public libraries as public spaces and to strengthen that role by placemaking, by involving citizens in planning of libraries and their services." Berndtson, supra note 101 at 1.

116 Cohl \& Thomson, supra note 44 at 34-35. 
Centres in Ontario (and recently, Saskatchewan) already conduct legal information sessions providing materials to members of the public, ${ }^{117}$ a model easily replicable in the public library setting as another means for expanding information access. The BC Courthouse Library through the LawMatters Project provides training and support to librarians in small public libraries ${ }^{118}$ including "bibliographies of recommended current resources, research guides on specific legal topics, training for public library staff, reference and referral support, and financial assistance to purchase appropriate legal resources." 119 The $\mathrm{BC}$ initiative looks at the type of reference resources required in public libraries, the type of training required by library staff and the need for community forums designed to encourage inter-agency cooperation in meeting the community needs for public legal information. ${ }^{120}$

The Five County Project in Ontario, as another example, set out to determine the potential that libraries have to improve access to legal information ${ }^{121}$ and therefore justice, for SRLs, especially those residing in rural and remote regions. In the "course of interviewing 'people helpers' [they] held a focus group with public librarians [and] discovered [they] were very interested in helping people access credible and free legal information." 122 Librarians were eager to learn "what role public library staff could play to connect people dealing with common legal problems to the justice resources that they needed" as well as building skills at "'red-flagging' legal issues and displaying plain language legal information." 23 Part of the Five County Project; Leering's "Librarians \& Access to Justice Outreach Project" partnered with libraries for five years to explore how to "narrow the 'justice gap' for our communities," ${ }^{124}$ seeking to share findings with other jurisdictions. ${ }^{125}$

The Five County Project also launched the "Legal Education \& Advocacy Regional Network" [LEARN], setting out to strengthen partnerships with non-legal organizations "in order to improve identification of legal issues, map existing access points in communities, and create accurate and comprehensive referral resources." ${ }^{26}$ LEARN workshops utilize volunteer lawyers, but since they are

17 Ibid at 42.

118 Malcolmson, supra note 33 at 94.

119 Cohl \& Thomson, supra note 44 at 37.

120 Five County Connecting Region Project, supra note 49 at 31. In fact, in a recent report, founding Courthouse Libraries BC LawMatters Program Coordinator Janet Freeman and Nancy Hannum, LawMatters Program Consultant highlight the ground-breaking nature of the $\mathrm{BC}$ initiative:

...[F]rom 1975 to 2002, and 2007 to the present day, BC was the first jurisdiction in Canada, and quite likely the English-speaking world, to develop an ongoing program to help public libraries provide legal information to the public, [with] [a] review of legal literature [finding] only one similar program: the Legal Information Access Centre (LIAC) of New South Wales, Australia, which operated from 1990 - 2014, and cited the BC Public Libraries Program as its model.

Janet Freeman \& Nancy Hannum, 'LawMatters at your local public library' a history of CB 's program for public legal information and education in public libraries (Toronto: Canadian Forum on Civil Justice, 2015) at 3.

121 Leering, "Libraries, supra note 70 at 2.

122 Michele Leering, "Justice at Your Library?" (1 September 2015), PLE Case Studies, online: $<\mathrm{http}: / /$ www.plelearningexchange.ca/justice-at-your-library/>.

123 Ibid.

124 Ibid.

125 Ibid at 1.

126 Five County Connecting Region Project, supra note 49 at 6. 
not well attended, potentially due to a lack of anonymity, Leering recommends delivery via webinar. ${ }^{127}$ The Five County Project meanwhile, led to the creation of workshops for librarians relating to access to legal information and public legal education. ${ }^{128}$ The Project also led to initiatives to share their approach (such as attendance at conferences), ${ }^{129}$ an information and advice "hotline" for "trusted intermediaries," 130 a database of libraries instituted by Community Legal Education Ontario (CLEO) to keep services updated, ${ }^{131}$ and Community Advocacy \& Legal Centre meetings with librarians for the purpose of maintaining quality collections. ${ }^{132}$ Above are just a few examples of cooperative and integrative initiatives already underway in Canada incorporating public library staff, legal professionals, and various organizations to improve access to legal information both in regions of need and for patrons in need. ${ }^{133}$

Cohl and Thomson provide further advice on initiatives that could help. They contend, "[w]e need to create a system, not an entity, [providing] multiple points of access," since supplying every small community with a justice access triage centre is infeasible. ${ }^{134}$ These authors map the ideal coordinated system wherein a person consults a non-legal organization, with occasional assistance from legal professionals, to learn about legal components of their problem. The legal community would support institutional capacity for a "trusted intermediary" to provide information to the individual. Meanwhile community workers could help legal professionals understand the needs of vulnerable clients. ${ }^{135}$

Strategies for improving the capacity of intermediaries could include training, "real-time legal help for front-line workers and access to public legal education materials in a variety of languages and

127 Leering, "Libraries", supra note 70 at 10.

128 Five County Connecting Region Project, supra note 49 at 36.

129 Leering, "Libraries", supra note 70 at 9.

130 Ibid at 10.

131 Ibid at 13.

132 Five County Connecting Region Project, supra note 49 at 23.

133 See the CFCJ's literature view, supra note 31 at 50-51 for more examples of promising initiatives serving SRLs in rural and remote areas across North America.

134 Cohl \& Thomson, supra note 44 at 54 [emphasis added]. Locally, the idea of "justice access centres" or "integrated service centres" was discussed at the 2014 meeting of the Dean's Forum on Access to Justice and Dispute Resolution at the College of Law, University of Saskatchewan. Students in the Dean's Forum course prepared a policy discussion paper on the topic. Dean's Forum Summer Student Researchers were hired to complete further community-engaged research "on the ground" regarding creating a "system" of integrated service delivery in Saskatchewan. The two student researchers "spoke with and visited roughly 30 legal and social community-based organizations" in Saskatchewan to "extract information about the organization and their views regarding an integrated service delivery model". The students wrote a paper on "emerging themes", as well as a paper that "proposed strategies and initiatives for advancement" of integrated service delivery. See University of Saskatchewan College of Law, "Bridging the Gap: The Prospect of Integrated Service Centre" (13 March 2014), online: <http://law.usask.ca/documents/deansforum/03_TheProspectofIntegratedServiceCenters2014DeansForum.pdf $>$ [unpublished] for the Dean's Forum course student's policy discussion paper and University of Saskatchewan, College of Law, “The Dean's Forum on Dispute Resolution and Access to Justice: Progress Report” (March 2015), online: <http://law.usask.ca/documents/deansforum/05_ProgressReportI_20142015.pdf $>$ [unpublished] [Progress Report] for the summer students' work. The Progress Report includes the papers (i) "Emerging Themes in Early and Integrated Service Delivery" (Appendix A at 6); and (ii) "Improving upon Early and Integrated Service Delivery" (Appendix B at 39).

135 Ibid at 61-62. 
formats." 136 Intermediaries must be capable of understanding "key legal issues relevant to their clients," 137 the limits of legal assistance that can be provided by non-lawyers, and how to make appropriate referrals. ${ }^{138}$ Malcolmson suggests the following strategies: "(a) creating legal gateway sites that take into account the lack of user searching skills; (b) promoting these sites to relevant intermediaries; and (c) increasing the knowledge and skill level of intermediaries." ${ }^{139}$ Legal professionals could even provide summary advice sessions to client groups in areas of greatest need. ${ }^{140}$ Ultimately, community organizations and legal partners must be connected in order to increase awareness of the needs of vulnerable people ${ }^{141}$ and to ensure that SRLs and LSR clients have access to vital legal resources, as well as the means to effectively employ said resources to meet the specific needs that their legal issues present.

To build a coherent system in which public libraries serve as a primary entry point for people seeking legal information, where other kinds of law libraries and players in the justice system play a supporting role, it will be necessary to ensure that public librarians have adequate training to assess and interpret legal information, that they have a suitable collection of resources available to them, and that they are comfortable with the distinction between providing access to legal information and providing legal advice. It is to these three issues that we now turn.

\section{Building Legal Information Collections in Public Libraries}

Courthouse libraries have well-established criteria for maintaining a "core collection" to serve their professional clients, and academic law libraries also have fairly developed approaches to building their collections, but there are fewer standard guides for public library legal collections. ${ }^{142}$ Since public libraries can provide basic legal resources and serve as gateways to access to legal information, ${ }^{143}$ their capacity for providing effective access to legal information should be enhanced. The AALL acknowledges the importance of maintaining a core collection of legal materials and the likely need for sharing agreements "with other public libraries, along with effective referrals to local law libraries open to the public." ${ }^{144}$ Meeting general guidelines for currency of these materials, ensuring legal websites are authoritative, and utilizing only reputable publishers are good practices in any library. Law society and courthouse libraries can assist their public partners with "collection-building projects" with the goal of keeping public collections effective and up-to-date. ${ }^{145}$

The most important consideration in ensuring that public access to legal information is maximized is how to get the information to the trusted intermediaries working the public library reference desk, who in the model we have outlined would be the first point of contact for those seeking legal

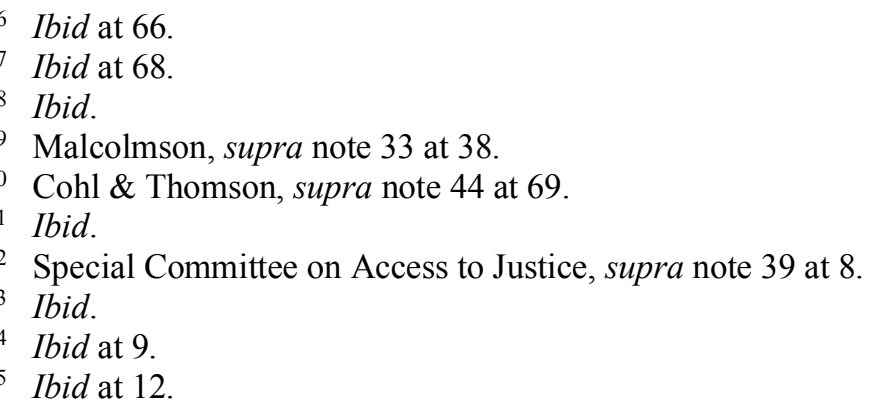


information. ${ }^{146}$ Technology can be used to link public librarians with other libraries, public legal education resources, and advice about building an adequate collection of legal information resources for the public. The Five County Project in Ontario recommended the development of a public website for all the "outreach, legal information and legal education resources," 147 an efficient use of technology of the type that the AALL considers a benefit for linking small libraries to remote but helpful services. ${ }^{148}$ Exploring the ways technology can close the justice gap by providing a "remote legal self-help service" can provide clients and intermediaries with online self-help resources, phone and/or live-chat, or even video access to legal advice. ${ }^{149}$

There are challenges associated with building legal information collections in public libraries. These include the frequent need for updating and revision of the collections, offering collections in accessible language, and the expenses associated with maintaining the collections. To date, as was discussed at our SALI Project meeting, law-related materials tend to come in the form either of brief plain-language leaflets about legal subject matter, or dense technical articles and books in digital or print form. ${ }^{150}$ In most cases, the format of the materials is based on the premise a legal professional will be the one to understand or explain the information to the extent it needs to be explained. Service providers have described multiple ways they identify relevant websites and provide assistance, but as Malcolmson points out, the real challenge is to "present the information in a range of different formats to accommodate different learners." 151 Broadly speaking, a librarian must also strive to find pertinent information for that specific customer, not merely relevant information. According to Anderson, information becomes pertinent "if the customer perceives it to be about the subject of his or her information need." 152 As we have seen, there is a wide range of capacities and needs among users of legal information, and it is necessary for public librarians to be able to find information suitable to a particular constituency and to assist in its use.

Librarians have experienced these challenges before and have attempted to be proactive in answering legal questions and responding to user needs. ${ }^{153}$ If a range of resources at different levels of complexity were created for SRLs and LSR clients for legal reference purposes, the library staff could provide limited assistance so that the patron can adequately perform the research. ${ }^{154}$ They would thereby fulfill their reference duties. Condon suggests a "mid-range" approach to reference involving analysis of the patron's needs with the use of the service as a primary objective. ${ }^{155}$ According to Condon:

146 Malcolmson, supra note 33 at 95.

147 Five County Connecting Region Project, supra note 49 at 46.

148 Special Committee on Access to Justice, supra note 39 at 7.

149 Malcolmson, supra note 33 at 96.

150 This comment is attributed to Christine Varnam, SALI Project partner, through her observations as a legal librarian at the Saskatoon Public Library.

151 Malcolmson, supra note 33 at 78.

152 Anderson, supra note 76 at 14.

153 Malcolmson, supra note 33 at 10.

154 Condon, supra note 77 at 172.

155 Ibid at 168. 
[A]nalysis should be made to determine whether the question requires more guidance or actual legal advice. If guidance is all that is required, the librarian can provide instruction in the use of resources and answer questions related to the use of the materials, but not interpret the content. ${ }^{156}$

Librarians could employ examples unrelated to the patron's actual case when demonstrating how to properly use a reference resource, and could be supplied with instructional handouts on how to read cases and locate statutes. The librarian should "feel free to direct the patron to confer with an attorney" if this reference assistance is ultimately insufficient. ${ }^{157}$ Public librarians therefore must be equipped with the appropriate tools and resources to provide the most effective access to legal information they can, whether that information is in the library or elsewhere.

Unfortunately, Leering's findings were that reference holdings were out-dated due to lack of funding, which is a serious issue since "wrong information can potentially be more dangerous than no information." 158 With respect to building legal information collections in libraries, she suggests special training of librarians in legal resources; linking these resources on the library homepage; developing tip sheets for meeting with lawyers; and providing a guide to legal aid. ${ }^{159}$ Helping librarians to identify what materials have become obsolete and to devise strategies for finding more current information is an important aspect of the training that should be made available. Leering acknowledges the courthouse librarian's efforts to update annually their list of recommended resources and to fund the purchase of important texts; ${ }^{160}$ this is an example of the assistance courthouse and academic libraries might provide to support public librarians. Condon calls for collection development policies for patron legal information materials, referral lists, legal information brochures, and guides for patrons accessing legal websites. ${ }^{161}$ The building of legal information collections in public libraries and the ability of library staff to assess the resources in those collections is essential. Furthermore, these challenges incentivize collaboration among the public, law/courthouse, and academic law library systems that makes the best use of collections and resources among these systems.

Mere availability of information does not guarantee effective access. This is why the CFCJ suggests, "training trusted intermediaries to identify legal issues and coordinate referrals is a 'key factor to successful service delivery in rural [and urban] contexts." "162 These trusted intermediaries become critical for providing access to those individuals challenged by distance from traditional service providers ${ }^{163}$ or lacking in sufficient resources. The training of public library staff is discussed next.

\footnotetext{
156 Ibid.

157 Wendi Arant \& Brian Carpenter, "Where is the Line? Legal Reference Service and the Unauthorized Practice of Law (UPL) - Some Guides That Might Help" (1999) 38:3 Reference \& User Services Q 235 at 237-238.

158 Leering, "Libraries", supra note 70 at 4.

159 Ibid at 4-8.

160 Ibid at 11-12.

161 Condon, supra note 77 at 171-172.

162 Canadian Forum on Civil Justice, supra note 31 at 38-39.

163 Five County Connecting Region Project, supra note 49 at 12.
} 


\section{Building Legal Information Training for Public Library Staff}

Even at the beginning stages of our consultations with public librarians through the SALI project, they have identified training as a priority need if they are to be effective in assisting patrons dealing with legal issues. We have earlier spoken of barriers to courthouse or law school libraries becoming feasible primary access points for members of the public seeking legal information. An alternative role that might profitably be played by specialized law librarians and members of the legal profession would be as trainers and mentors for public librarians. Legal professionals could follow the lead of Ontario and $\mathrm{BC}$ to provide legal awareness workshops for service providers ${ }^{164}$ in order to increase the capacity of trusted intermediaries like library staff to identify when clients have legal problems. ${ }^{165} \mathrm{In}$ fact, there is evidence from initiatives in Ontario and $\mathrm{BC}$ that indicate an interest in training and its impact among trainers and trainees, alike. For example, over the course of her project, Leering found that lawyers in the community were interested in recommending good legal reference books and offering legal information sessions, and a key conclusion of a final report of the LawMatters Project found that nearly all trainees responded positively to training, including a rise in long-lasting confidence levels among library staff and an interest in ongoing training. ${ }^{166}$ Legal professionals could provide libraries with basic legal information and/or "warm referrals to appropriate legal services (including websites and telephonebased services)." 167 Such "warm referrals" can both reduce referral fatigue ${ }^{168}$ and support user empowerment.

With respect to training, the AALL, for example, suggests classes at the library, presentations aiding librarians in training their own staff, and encouraging communications with local law libraries. ${ }^{169}$ The AALL suggests law/courthouse librarians can teach public librarians "basic legal research skills, how to conduct an effective legal reference interview, and how to avoid the unauthorized practice of law" which is an idea that the LawMatters Project has already taken up through their three-prong approach to training public library staff: (i) a training webinar on searching "QP LegalEze", a legal database that is accessible to all $\mathrm{BC}$ public libraries; (ii) introductory workshops on legal reference training; and (iii) an extensive eight-week online course for public library staff. ${ }^{170}$

Law/courthouse librarians are "very familiar with the types of issues self-represented litigants bring to the library, and they are experienced in techniques for drawing the line" 171 in order to avoid unauthorized practice, a consideration addressed in the next section. Law/courthouse librarians are a common gatekeeper to legal information and could facilitate its dissemination to the public and help

164 Ibid at 20. See also an extensive evaluation of the training associated with the BC LawMatters Project: Focus Consultants, LawMatters Public Library Legal Resources Project: Final Training and Legal Reference Survey Findings Final Report (Victoria, BC: Focus Consultants, 2010).

165 Five County Connecting Region Project, supra note 49 at 45.

166 Leering, "Libraries", supra note 123.

167 Ibid at 45.

168 Ibid.

169 Special Committee on Access to Justice, supra note 39 at 11.

170 Special Committee on Access to Justice, supra note 39 at 8. For more information on the three types of training that LawMatters provides, see Focus Consultants, supra note 164 at 4 and a summary and conclusions about the impact of LawMatters training on trainees at 24 .

171 Ibid at 11. 
explain the means for employing it. ${ }^{172}$ They can achieve this, in part, by helping to establish public libraries as an access to justice entry point for credible and current legal information.

It is possible that academic law librarians and law schools could also contribute to the training of public librarians. Many law schools are examining ways to extend their programming in relation to access to justice, and to involve their students and faculty in projects that will further their understanding of the challenges facing the justice system in this regard. Libraries associated with law schools might be appropriate venues for continuing professional education courses or certificate programs focused on building the capacity of public librarians to serve as a primary access point for legal information.

\section{Building Awareness and Tools for Public Library Staff to Clarify the Distinction Between Providing Legal Information and Legal Advice}

(a) Building awareness about the distinction between providing legal information and legal advice in the library context

We observed early in this paper that one of the challenges in extending access to legal information arises from the monopoly that licensed lawyers have over the provision of legal services. The definitions of the practice of law in regulatory statutes tend to be quite broad. The Saskatchewan Legal Profession Act, 1990 for example, contains the following provision:

30(1) No person, other than a member who holds a certificate, shall: ...

(b) advise, do or perform any work or service for fee or reward, either directly

or indirectly, in matters pertaining to the law of Saskatchewan or of any

jurisdiction outside Saskatchewan. ${ }^{173}$

Though there are signs that law societies are beginning to examine the question of whether the practice of law needs to be defined in such broad terms, and whether the breadth of the definition in itself inhibits innovation in providing access to justice, there will continue to be an important distinction between providing legal information and providing legal advice within the framework of the solicitor-client relationship.

The challenge of avoiding the practice of law is an extremely important one to consider for trusted intermediaries such as library staff completing legal reference work. It is not only a legal rule that librarians must not conduct unauthorized practice of law. When offering legal help to patrons, American law librarians are to adhere to ethical guidelines set out by the AALL, limiting the scope of assistance that they can provide. ${ }^{174}$ Whilst providing useful reference work, librarians have an obligation to distinguish themselves from those licensed to provide legal advice. In order to identify potential legal

Ibid at 44.

173 SS 1990, c. L-10.1.

174 Noel, supra note 29 at 261. 
issues, however, librarians will have to conduct a thorough reference interview. ${ }^{175}$ Library staff must foster a close relationship with a patron in order to discover "his or her 'real' or 'true' information need, even though this risks crossing the line into legal representation." ${ }^{\prime 176}$ This is where the risk arises. It is in the role of interpreter that librarians encounter the issue of the potential provision of legal advice when they wished only to provide reference assistance. ${ }^{177}$ Some argue that there is also a risk that "patrons see the law librarian as the equivalent of a legal adviser, not as an information provider." 178 Given this close relationship and inherent risk, librarians should make it clear that the relationship they have with their patrons cannot be the basis for the provision of actual legal services.

Yet, writing about the similar difficulties faced by court staff, John Greacen acknowledges the unhelpful use of the vague term, "legal advice." In his opinion, oversensitivity to this issue causes court staff to "limit unnecessarily the flow of information to the public about court operations and it creates opportunities for discrimination among different categories of court users." ${ }^{179}$ According to Madison Mosley, in the context of library staff, "[p]ointing to sources of information or showing a person how a resource is used and walking away is not reference work. The reference librarian is the 'interpreter of the library to readers" "' 180 after all. What could be helpful is a working definition of what is and what is not the practice of law. ${ }^{181}$ Unfortunately, this definition is difficult to find, and may differ depending on contexts. ${ }^{182}$ Despite the difficulty of defining a clear distinction between legal information and legal advice, a considerable amount of guidance can be afforded to librarians to ensure that they are capable of supplying quality legal reference work without risking the provision of legal advice.

\section{(b) Guidance and Tools to Clarify the Distinction Between Legal Information and Legal Advice in the Library Context}

There is literature, accompanied by strategies and tools, that provides some guidance on how library staff might navigate the distinction. Steven Anderson, quoting Mark Sanders, offers such guidance in suggesting that library staff doing legal reference work must not "interpret" the law or say that a given statute or case "is the law." 183 Instead, they may refer to general provisions and translate

175 Joan Allen-Hart, "Chapter 4: Legal Reference vs. Legal Advice" in June Kim, ed, Locating the Law: A Handbook for Non-Law Librarians, $5^{\text {th }}$ ed, (Public Access to Legal Information Committee, Southern California Association of Law Libraries, 2011), online: <http://scallnet.org/wp-content/uploads/2016/03/ch4.pdf $>$ at 48.

176 Anderson, supra note 76 at 6.

177 Madison Mosley Jr, "The Authorized Practice of Legal Reference Service” (1995) 87:1 Law Library J 203 at 203.

178 Malcolmson, supra note 33 at 168.

179 John M Greacen, "Legal Information vs. Legal Advice: Developments During the Last Five Years" (2001) 84:4 Judicature 198 at 198.

180 Mosley Jr, supra note 177 at 203.

181 Ibid at 203-204.

182 Law students and justice stakeholders undertook a research and exploratory analysis of the topic of legal information, legal advice, and access to justice in various contexts during the fifth meeting of the Dean's Forum on Access to Justice and Dispute Resolution at the College of Law, University of Saskatchewan. The students' policy discussion paper and the themes arising from the justice stakeholders' discussion will be made available here: University of Saskatchewan College of Law Reports: Dean's Forum Library, online: <http://law.usask.ca/research/deans-forum/library.php>. 
abbreviations. ${ }^{184} \mathrm{~A}$ librarian can consider assistance complete when the materials needed "to answer the question have been located." 185 Lawyers, not librarians, are deemed experts in interpreting and applying the law, whose profession is the provision of legal advice.

When individuals visit the library they are merely seeking reference help, an attempt to obtain specific information for their legal problem. ${ }^{186}$ Most patrons are probably well aware of this distinction if only on a practical level. Still, although "no reported cases indicate that librarians have been charged with unauthorized practice, reference librarians [are] governed by ethical principles and assistance must be carefully limited." 187 So, though some argue that SRLs or LSR clients be treated like any other library user, Condon suggests that in fact, traditional approaches to reference "must be evaluated in light of the librarian's duty to avoid practicing law." "188 First and foremost, librarians must not provide an opinion that inadvertently influences the user in "deciding not only what his or her specific legal issue may be, but also the course of action which should be taken." 189 Not only is it against the law, it might also be detrimental to a patron dealing with a personal legal matter. ${ }^{190}$

The distinction between assistance and advice may not always be clear, thus Mosley thinks it is easier for a librarian to consider not what practicing law would constitute, but rather to concentrate on not performing "lawyerly functions." identifies that a lawyer, as advisor, "gives clients 'an informed understanding of [their] legal rights and obligations, and explains their practical implications." ${ }^{192}$ She also indicates that no group "has a monopoly on the literature of a field and its use," ${ }^{193}$ including lawyers. Besides, many argue that the "dismantling of the bar's monopoly on the communication of legal services, presents a tremendous opportunity in closing the justice gap," bringing with it implications for librarianship. ${ }^{194}$ Librarians must not be more concerned about whether they are giving legal advice than whether they are adequately answering a reference question, lest they afford the legal profession "more authority than it should have in defining what is proper in the provision of information services." 195 Reference librarians are not performing "lawyerly functions" says Mosley, when they supply research materials, including citations, to SRLs or LSR clients. In her opinion, unauthorized practice of law generally targets non-lawyers performing such functions. ${ }^{196}$ A search discloses elements, which must be put together and given meaning by the application of logic, and librarians must remember that it is the "lawyer's function to

Ibid.

Ibid.

186 Mosley Jr, supra note 177 at 207.

187 John D Edwards, Emerging Solutions in Reference Services: Implications for Libraries in the New Millennium (Binghamton, NY: The Haworth Information Press, 2001) at 170.

188 Condon, supra note 77 at 166.

189 Allen-Hart, supra note 175 at 47.

190 Special Committee on Access to Justice, supra note 39 at 236.

191 Mosley Jr, supra note 177 at 205.

192 Ibid.

193 Ibid at 206.

194 Noel, supra note 29 at 253.

195 Mosley Jr., supra note 177 at 209.

$196 \mathrm{Ibid}$ at 206. 
apply this logic and then, based on his or her experience, suggest to the client probable outcomes."197 That may be the clearest definition possible for what qualifies as legal advice.

In addition to building awareness for public library staff to clarify the distinction between providing legal information and legal advice, there are several tools from related literature that can be implemented to help clarify this distinction. Condon recommends using a sign stating that librarians provide access to legal information and not advice. This serves as a reminder to patrons ${ }^{198}$ and potentially qualifies as a legal disclaimer. ${ }^{199} \mathrm{~A}$ written statement can also achieve this end, and even help staff understand their limitations, but ultimately all staff should be educated in legal reference assistance including avoiding unauthorized practice. ${ }^{200}$ Relatedly, Paul Healey argues,

$[R]$ eference policies relating to pro se patrons are ones that all libraries should follow. [Such policies] relating to the treatment of pro se patrons, including acceptable and unacceptable activities, should be developed, all staff having contact with the public should be trained on them, and the policies should be disseminated to all interested parties, including, in perhaps shortened form, to the patrons themselves. ${ }^{201}$

Librarians must rely on their code of ethics in the absence of clear legal rules guiding their behaviour. ${ }^{202}$ Access to information is the mandate of the librarian. ${ }^{203}$ Clients require a high level of literacy and comprehension in order to make effective use of legal resources. Librarians should help them to "understand the material provided and be able to effectively pursue their own interests." 204 That is the best way of framing the boundary that a librarian must not cross. When serving an SRL, note that they are just that, self-represented. A librarian can and should give patrons all the reference assistance that they require in order to independently determine the answers to their own questions. ${ }^{205}$ Short of that a librarian can still accomplish a fair bit, recommending books and other sources, teaching legal research techniques, and helping in the construction of searches. ${ }^{206}$ Simply put, the librarian who "takes over the user's legal question by interpreting and making conclusions" about it is one who crosses the line into

197 Ibid at 208.

198 Condon, supra note 77 at 171.

199 Special Committee on Access to Justice, supra note 39 at 237.

200 Allen-Hart, supra note 175 at 51; and see the Legal Awareness/Legal Advocacy Continuum of the Five County Connecting Region Project, supra note 49 at 45.

201 Paul Healey, "I Can Help You: Legal Information vs. Legal Advice" (2000) 5:1 AAL Spectrum 18 at 18.

202 Larry D Richmond Jr, "The Pro Se Patron: An Ethical Rather than Legal Dilemma" (2003) 22:2-3 Legal Reference Services Q 75 at 79.

203 The duty to refrain from giving legal advice may constrain facilitation of access, but Noel argues that librarians have an "affirmative ethical duty to eliminate any unnecessary barriers to legal information wherever possible." Noel, supra note 29 at 261. This follows the AALL Code's call for a duty of the law librarian "to promote any access to the law that is not limited by the risk of unauthorized practice." Noel, ibid at 262.

204 Malcolmson, supra note 33 at 31 [emphasis added].

205 Allen-Hart, supra note 175 at 48. It is imperative, says Allen-Hart, that users "research their own issues and come to their own conclusions about how the law applies."

206 Ibid at 48. 
unauthorized practice. ${ }^{207}$ All the reference assistance provided without crossing that line does more good than harm to a user's legal situation. ${ }^{208}$

Thus, much can be done through partnerships between public libraries and courthouse and academic law libraries to improve the justice gap and establish public libraries as a primary access to justice entry point. As was detailed in the above four subsections, the capacity of public libraries to help reduce the justice gap can be supported by learning and building on current legal information initiatives with libraries in Canada; building legal information collections in public libraries; building legal information training for public library staff; and building awareness and tools for public library staff to clarify the distinction between providing legal information and legal advice.

\section{CONCLUSION}

Improving access to justice in Canada necessarily requires improving community organizational and institutional capacity to serve as effective entry points. The rise of SRLs and increasing popularity of the use of LSRs, which contexts were described in Part I, increases the need for more open and effective access to legal information and the involvement of trusted intermediaries in public spaces like libraries to answer these informational needs. The unique and symbiotic roles that the law society/courthouse library, academic law library, and public library systems could undertake in improving access to legal information was detailed in Part II. Finally, despite reservations and potential risks ${ }^{209}$ the case was made in Part III as to why and how public libraries and their staff should be invited and supported to serve as "trusted intermediaries" of the justice system. Finally, Part III outlined initiatives that are underway, and three key areas to build upon: building legal information collections, training, and awareness and tools about legal information for public libraries.

Further collaboration and integration should be pursued among the library systems and justice organizations. Data collection and empirical research should accompany new projects and innovations, in order to gauge and document best practices. ${ }^{210}$ Such steps will improve the capacity of libraries, and specifically public libraries, with the support of law/courthouse and academic law libraries, to better serve the needs of patrons with legal problems, providing access to crucial legal information, reference assistance, and the tools for these patrons to more ably administer self-help. With a significant number of members of the public in the justice gap, and the burgeoning sea of online legal information resources, the "data hound... guide... Sherpa... and ...teacher" that Seth Godin describes as the "librarian" represents a promising intermediary in the provision of legal information.

Ibid.

208 Ibid at 52.

209 If the reader is still not fully convinced of the realistic means for providing effective access to legal information and reference assistance whilst avoiding legal advice and the unauthorized practice of law, see Joan Allen-Hart's helpful chart and the Council of California County Law Librarians' resource she outlines, ibid at 49-50.

210 The need for more data and empirical evidence to guide access to justice related reform was highlighted in both the Cromwell Report, supra note 1 at 23 and in the CBA Report, supra note 2 at 123 . A data collection tool is being piloted as part of the SALI Project through the support of CREATE Justice at a number of public libraries in Saskatchewan starting in May 2017. 